\title{
Quantitative Easing: Entrance and Exit Strategies
}

\author{
Alan S. Blinder \\ This article was originally presented as the Homer Jones Memorial Lecture, organized by the \\ Federal Reserve Bank of St. Louis, St. Louis, Missouri, April 1, 2010.
}

Federal Reserve Bank of St. Louis Review, November/December 2010, 92(6), pp. 465-79.

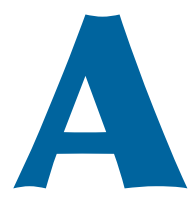

pparently, it can happen here. On December 16, 2008, the Federal Open Market Committee (FOMC), in an effort to fight what was shaping up to be the worst recession since 1937-38, reduced the federal funds rate to nearly zero. ${ }^{1}$ From then on, with all its conventional ammunition spent, the Federal Reserve was squarely in the brave new world of quantitative easing. Chairman Ben Bernanke tried to call the Fed's new policies "credit easing," probably to differentiate them from actions taken by the Bank of Japan (BOJ) earlier in the decade, but the label did not stick. ${ }^{2}$

Roughly speaking, quantitative easing refers to changes in the composition and/or size of a central bank's balance sheet that are designed to ease liquidity and/or credit conditions. Presumably, reversing these policies constitutes "quantitative tightening," but nobody seems to use that terminology. The discussion refers instead to the bank's "exit strategy," indicating that quantitative

\footnotetext{
1 Specifically, the FOMC cut the funds rate to a range between zero and 25 basis points. In practice, funds have mostly traded around 10 to 15 basis points ever since.

2 As will be clear later, the Fed's approach and the BoJ's approach were different.
}

easing is something aberrant. I adhere to that nomenclature here.

I begin by sketching the conceptual basis for quantitative easing: why it might be appropriate and how it is supposed to work. I then turn to the Fed's entrance strategy-which is presumably in the past, and then to the Fed's exit strategywhich is still mostly in the future. Both strategies invite some brief comparisons with the Japanese experience between 2001 and 2006. Finally, I address some questions about central bank independence raised by quantitative easing before briefly wrapping up.

\section{THE CONCEPTUAL BASIS FOR QUANTITATIVE EASING: THE LIQUIDITY TRAP}

To begin with the obvious, I think every student of monetary policy believes that the central bank's conventional policy instrument-the overnight interest rate (the "federal funds" rate in the United States)—is more powerful and reliable than quantitative easing. So why would any rational central banker ever resort to quantitative easing? The answer is pretty clear: Under

Alan S. Blinder is the Gordon S. Rentschler Memorial Professor of Economics and Public Affairs at Princeton University and co-director of Princeton's Center for Economic Policy Studies. He is also vice chairman of the Promontory Interfinancial Network. This paper is based on his Homer Jones Memorial Lecture at the Federal Reserve Bank of St. Louis, April 1, 2010. The author thanks Gauti Eggertsson, Todd Keister, Jamie McAndrews, Paul Mizen, John Taylor, Alexander Wolman, and Michael Woodford for extremely useful comments on an earlier draft and Princeton's Center for Economic Policy Studies for research support.

(C) 2010, The Federal Reserve Bank of St. Louis. The views expressed in this article are those of the author(s) and do not necessarily reflect the views of the Federal Reserve System, the Board of Governors, or the regional Federal Reserve Banks. Articles may be reprinted, reproduced, published, distributed, displayed, and transmitted in their entirety if copyright notice, author name(s), and full citation are included. Abstracts, synopses, and other derivative works may be made only with prior written permission of the Federal Reserve Bank of St. Louis. 
extremely adverse circumstances, a central bank can cut the nominal interest rate all the way to zero and still be unable to stimulate its economy sufficiently. ${ }^{3}$ Such a situation, in which the nominal rate hits its zero lower bound, has come to be called a "liquidity trap" (Krugman, 1998), although that terminology differs somewhat from Keynes's original meaning. ${ }^{4}$

Let's review the underlying logic. The presumption is that real interest rates $(r)$, not nominal interest rates (i), are what mainly matter for, say, aggregate demand. In deep recessions, monetary policymakers may need to push real rates $(r=i-\pi$, where $\pi$ is the rate of inflation) into negative territory. ${ }^{5}$ But once $i$ hits zero, the central bank cannot force it down any farther, which leaves $r$ "stuck" at $-\pi$, which is small or possibly even positive. In any case, once $i=0$, conventional monetary policy is "out of bullets."

Actually, the situation is even worse than that. Recall Milton Friedman's (1968) warning about the perils of fixing the nominal interest rate when inflation is either rising or falling: Doing so invites dynamic instability. Well, once the nominal rate is stuck at zero, it is, of course, fixed. If inflation then falls, the real interest rate will rise farther, thereby squeezing the economy even more. This is a recipe for deflationary implosion.

Enter quantitative easing. Suppose that, even though the riskless overnight rate is constrained to zero, the central bank has some unconventional policy instruments that it can use to reduce interest rate spreads-such as term premiums and/or risk premiums. If flattening the yield curve and/or shrinking risk premiums can boost aggregate demand, then monetary policy is not powerless, even at the zero lower bound. ${ }^{6}$ In that case, a cen-

\footnotetext{
3 Another argument is that a central bank might want to "save its bullets" for an even more dire situation. However, this argument was effectively debunked by Reifschneider and Williams (2002).

4 The Keynesian liquidity trap arises at the point where the demand function for money becomes infinitely elastic, which could happen at a nonzero interest rate.

5 The difference between ex ante expected inflation and ex post actual inflation is not important for this purpose.

6 Here I exclude exchange rate policy from monetary policy. Depreciating the exchange rate may be another option (see Svensson, 2003), though not when the whole world is in a slump.
}

tral bank that pursues quantitative easing with sufficient vigor can break the potentially vicious downward cycle of deflation, weaker aggregate demand, more deflation, and so on.

What unconventional weapons might be contained in such an arsenal? The following list is hypothetical and conceptual, but every item has a clear counterpart in something the Federal Reserve has actually done.

First, suppose the central bank's objective is to flatten the yield curve, perhaps because long rates have more powerful effects on spending than short rates. There are two main options. One is to use "open mouth policy." The central bank can commit to keeping the overnight rate at or near zero either for, say, "an extended period" (or some such phrase) or until, say, inflation rises above a certain level. To the extent that the (rational) expectations theory of the term structure is valid and the commitment is credible, doing so should reduce long rates and thereby stimulate demand. ${ }^{7}$ But such verbal commitments would not normally be considered quantitative easing because no quantity on the central bank's balance sheet is affected. So I will not discuss them further.

The quantitative easing approach to the term structure is straightforward: Use otherwiseconventional open market purchases to acquire longer-term government securities instead of the short-term bills that central banks normally buy. If arbitrage along the yield curve is imperfect, perhaps because asset holders have "preferred habitats," then such operations can push long rates down by shrinking term premiums. ${ }^{8}$

The other likely target of quantitative easing is risk or liquidity spreads. Every private debt instrument, even a bank deposit or a AAA-rated bond, pays some spread over Treasuries for one

\footnotetext{
7 While the expectations theory of the term structure with rational expectations fails every empirical test (see, for example, Blinder, 2004, Chap. 3), long rates do seem to move in the right direction, if not by the right amount.

8 The preferred habitat theory is attributed to Modigliani and Sutch (1966). It was one rationale, for example, for "Operation Twist," which sought to lower long rates while raising short rates in the early 1960s. Operation Twist, however, was not widely viewed as successful.
} 
or both of these reasons. ${ }^{9}$ Since private borrowing, lending, and spending decisions presumably depend on (risky) non-Treasury rates, reducing their spreads over (riskless) Treasuries reduces the interest rates that matter for actual transactions even if riskless rates are unchanged.

How might a central bank accomplish that? The most obvious approach is to buy one of the risky and/or less-liquid assets, paying either by (i) selling some Treasuries from its portfolio, which would change the composition of its balance sheet, or (ii) creating new base money, which would increase the size of its balance sheet. ${ }^{10}$ Either variant can be said to constitute quantitative easing, and its effectiveness depends on the degree of substitutability across the assets being traded. As we know, buying X and selling Y does nothing if $\mathrm{X}$ and $\mathrm{Y}$ are perfect substitutes. ${ }^{11}$ Fortunately, it seems unlikely that, say, mortgagebacked securities (MBS) are perfect substitutes for Treasuries-certainly not in a crisis.

\section{THE FED'S ENTRANCE STRATEGY}

With this conceptual framework in mind, I turn now to what the Federal Reserve actually did as it embarked on its new strategy of quantitative easing. Because the messy failure of Lehman Brothers in mid-September 2008 was such a watershed, I begin the story before that event.

Reacting somewhat late to the onset of the financial crisis in the summer of 2007, the FOMC began cutting the federal funds rate on September 18, 2007-starting from an initial target of 5.25 percent. While it cut rates rapidly by historical standards, the Fed did not signal any great sense of urgency. It was not until April 30,

9 In practice, it can be difficult to distinguish between spreads related to risk and spreads related to illiquidity. After all, illiquidity is one element of the riskiness of an asset. Hereafter, I simply refer to "risk spreads."

${ }^{10}$ Alternatively, if it has the legal authority, the central bank could (partially or totally) guarantee some of the risky assets or make loans to private parties who agree to buy the assets.

${ }^{11}$ Curdia and Woodford (2010) argue that the effectiveness of quantitative easing depends on the existence of "credit market frictions" rather than on imperfect substitutability. I think this difference is mostly terminological.

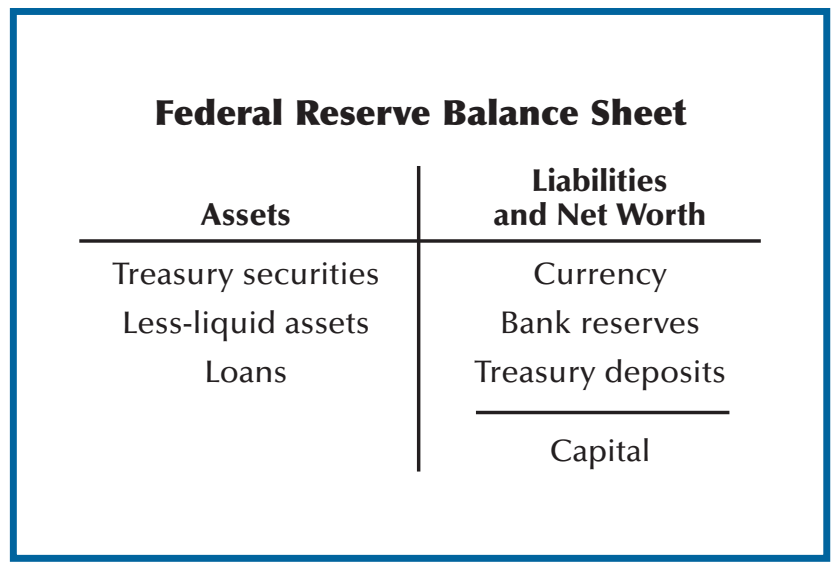

2008, that the target funds rate got down to 2 percent, where the FOMC decided to keep it while awaiting further developments (Figure 1). Perhaps more germane to the quantitative easing story, the Fed was neither expanding its balance sheet (Figure 2) nor increasing bank reserves (Figure 3) much over this period.

However, the Fed was already engaging in several forms of quantitative easing, even apart from emergency interventions such as the Bear Stearns rescue. To understand these brands of quantitative easing, it is useful to refer to the oversimplified central bank balance sheet in the box. Because other balance sheet items are inessential to my story, I omit them.

The first type of quantitative easing showed up entirely on the assets side. Early in 2008, the Fed started selling its holdings of Treasuries and buying other, less-liquid assets instead (see Figure 2). This change in the composition of the Fed's portfolio was clearly intended to provide more liquidity (especially more T-bills) to markets that were thirsting for it. The goal was to reduce what were seen as liquidity premiums. But, of course, the underlying financial situation was deteriorating all the while, and the markets' real problems may have been fears of insolvency, not illiquidity - to the extent you can distinguish between the two. ${ }^{12}$

The second sort of early quantitative easing operations began on the liabilities side of the Fed's balance sheet. To assist the Fed, the Treasury

${ }^{12}$ See, for example, Taylor and Williams (2009). 


\section{Figure 1}

\section{Effective Federal Funds Rate}

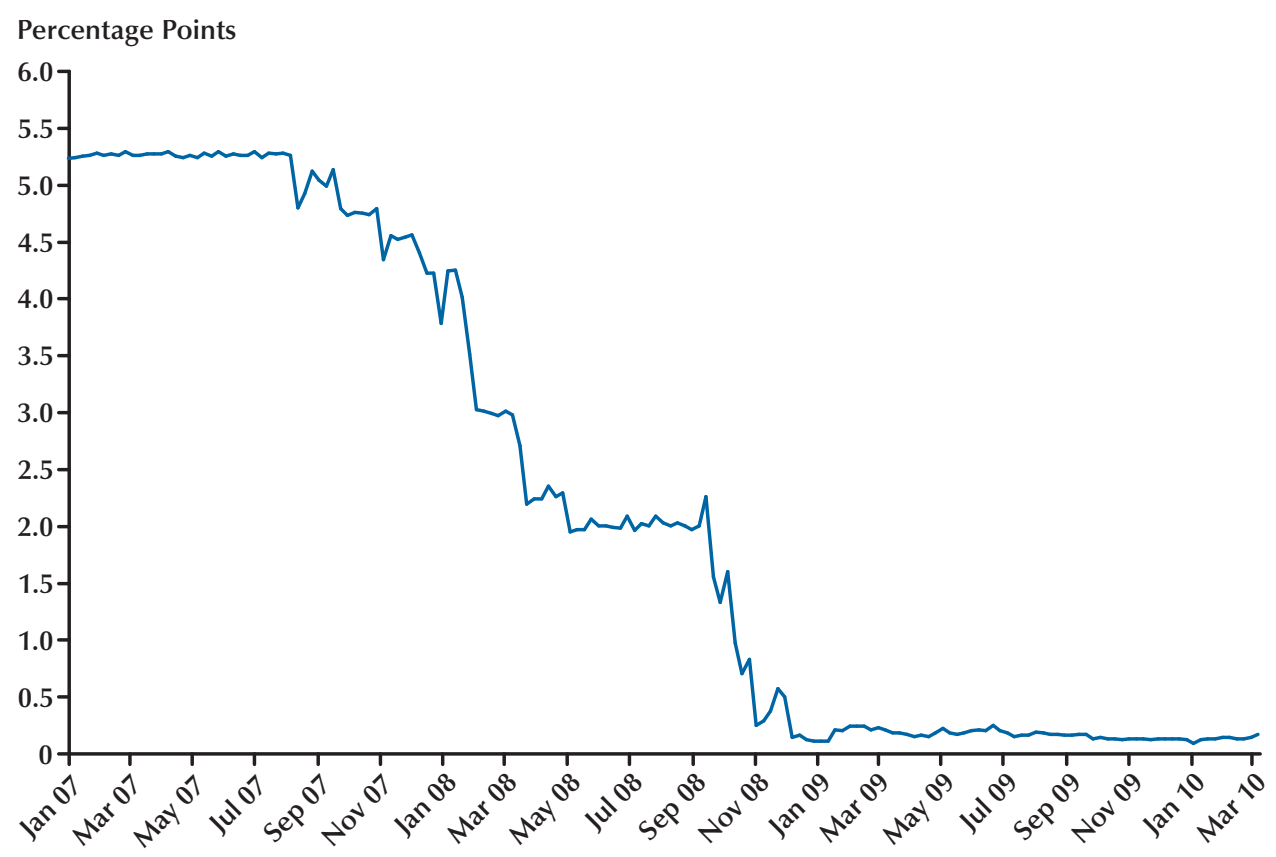

SOURCE: Federal Reserve.

started borrowing in advance of its needs (which were not yet as ample as they would become later) and depositing the excess funds in its accounts at the central bank. These were clearly fiscal operations, but they enabled the Fed to increase its assets-by purchasing more securities and making more discount window loans (e.g., through the Term Auction Facility [TAF])—without increasing bank reserves (see Figure 3). That is very helpful to a central bank that is still a bit timid about stimulating aggregate demand and/or is worried about running out of T-bills to sellboth of which were probably true of the Fed at the time. But notice that these operations marked the first breaching, however minor, of the wall between fiscal and monetary policy. In addition, the Fed began lending to (nonbank) primary dealers in the immediate aftermath of the Bear Stearns rescue in March 2008.

Six months later came the failure of Lehman Brothers, and everything changed-including the Fed's monetary policy. The FOMC resumed cutting interest rates at its October 10, 2008, meeting, eventually pushing the funds rate all the way down to virtually zero by December 16 (see Figure 1). More germane to the quantitative easing story, the Fed started expanding its balance sheet, its lending operations, and bank reserves immediately and dramatically (see Figures 2 and 3). ${ }^{13}$ By the last quarter of 2008, any reservations at the Fed about boosting aggregate demand were gone. It was "battle stations."

Total Federal Reserve assets skyrocketed from $\$ 907$ billion on September 3, 2008, to $\$ 2.214$ trillion on November 12, $2008^{14}$ (see Figure 2). As this was happening, the Fed was acquiring a

\footnotetext{
13 Taylor (2010) correctly points out that the Fed began expanding its balance sheet substantially even before the federal funds rate hit zero.

${ }^{14}$ Federal Reserve System balance sheets are published weekly and are available on the Board's website.
} 


\section{Figure 2}

\section{Composition of the Fed's Balance Sheet: Assets Side}

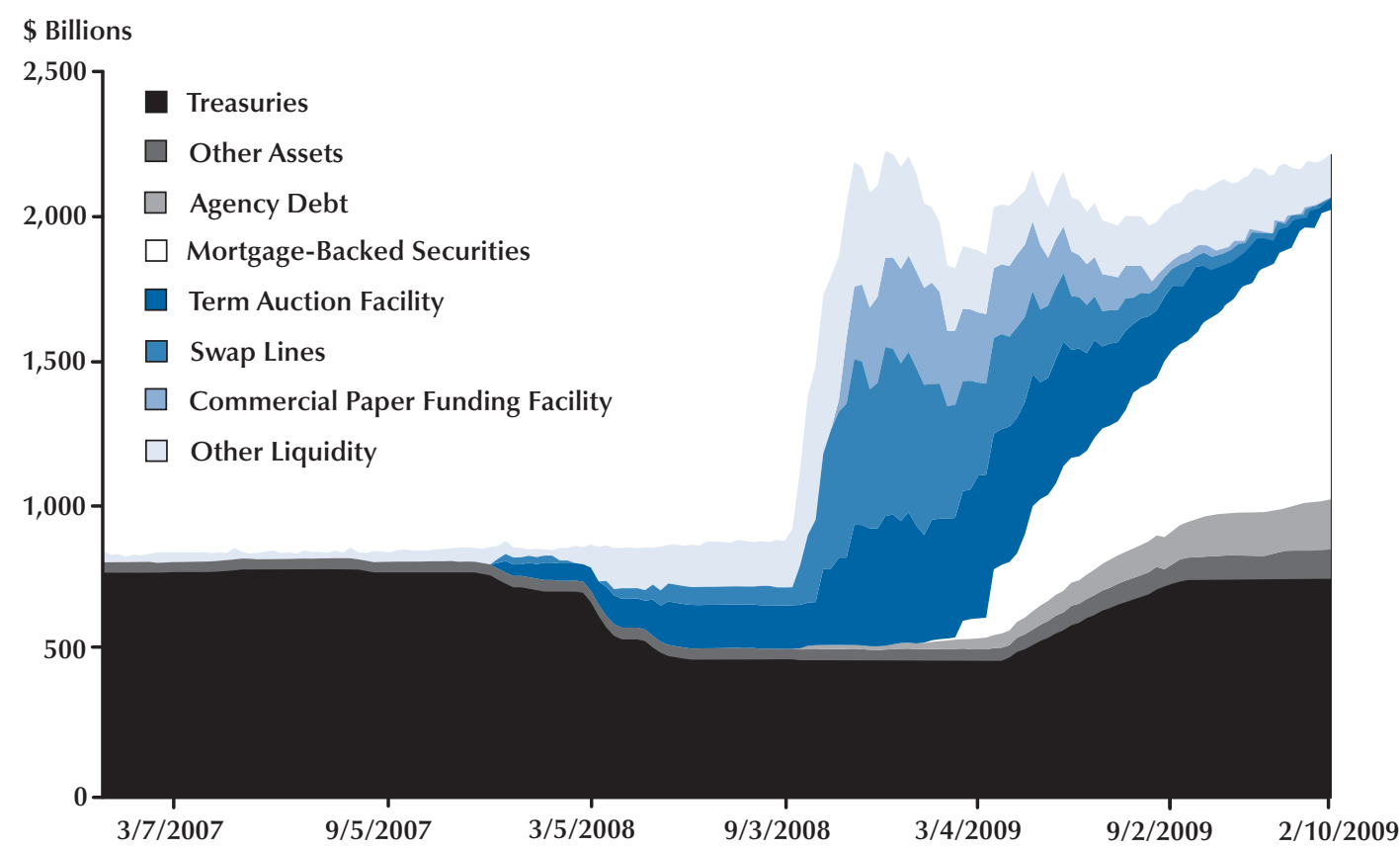

SOURCE: Federal Reserve Bank of New York.

wide variety of securities that it had not owned before (e.g., commercial paper) and making types of loans that it had not made before (e.g., to nonbanks). On the liabilities side of the balance sheet, bank reserves ballooned from about $\$ 11$ billion to an astounding $\$ 594$ billion over that same period-and then to $\$ 860$ billion on the last day of 2008 (see Figure 3). Almost all of this expansion signified increased excess reserves, which were a negligible $\$ 2$ billion in the month before Lehman collapsed (August) but soared to $\$ 767$ billion by December. ${ }^{15}$ Since the Fed's capital barely changed over this short period, its balance sheet became extremely leveraged in the process. Specifically, the Fed's leverage (assets divided by capital) soared from about 22:1 to about 53:1. It was a new world, Tevye. ${ }^{16}$

\footnotetext{
${ }^{15}$ These figures are monthly averages.

${ }^{16}$ A central bank can operate with negative net worth. Still, it is an uncomfortable position for the central bank.
}

The early stages of the quantitative easing policy were ad hoc, reactive, and institution based. The Fed was making things up on the fly, often acquiring assets in the context of rescue operations for specific companies on very short notice (e.g., the Maiden Lane facilities for Bear Stearns and American International Group [AIG]). Soon enough, however, the Fed's innovative parade of purchase, lending, and guarantee programs took on a more systematic, thoughtful, and market-based flavor-starting with the Commercial Paper Funding Facility (CPFF, begun in September 2008) and continuing with the MBS purchase program (announced November 2008), the Term Asset-Backed Securities Loan Facility (TALF, started in March 2009), and others. The goal became not so much to save faltering institutions, although that potential need remained, but rather to push down risk premiums, which had soared to dizzying heights during the panic- 


\section{Figure 3}

\section{Total Reserves of Depository Institutions}

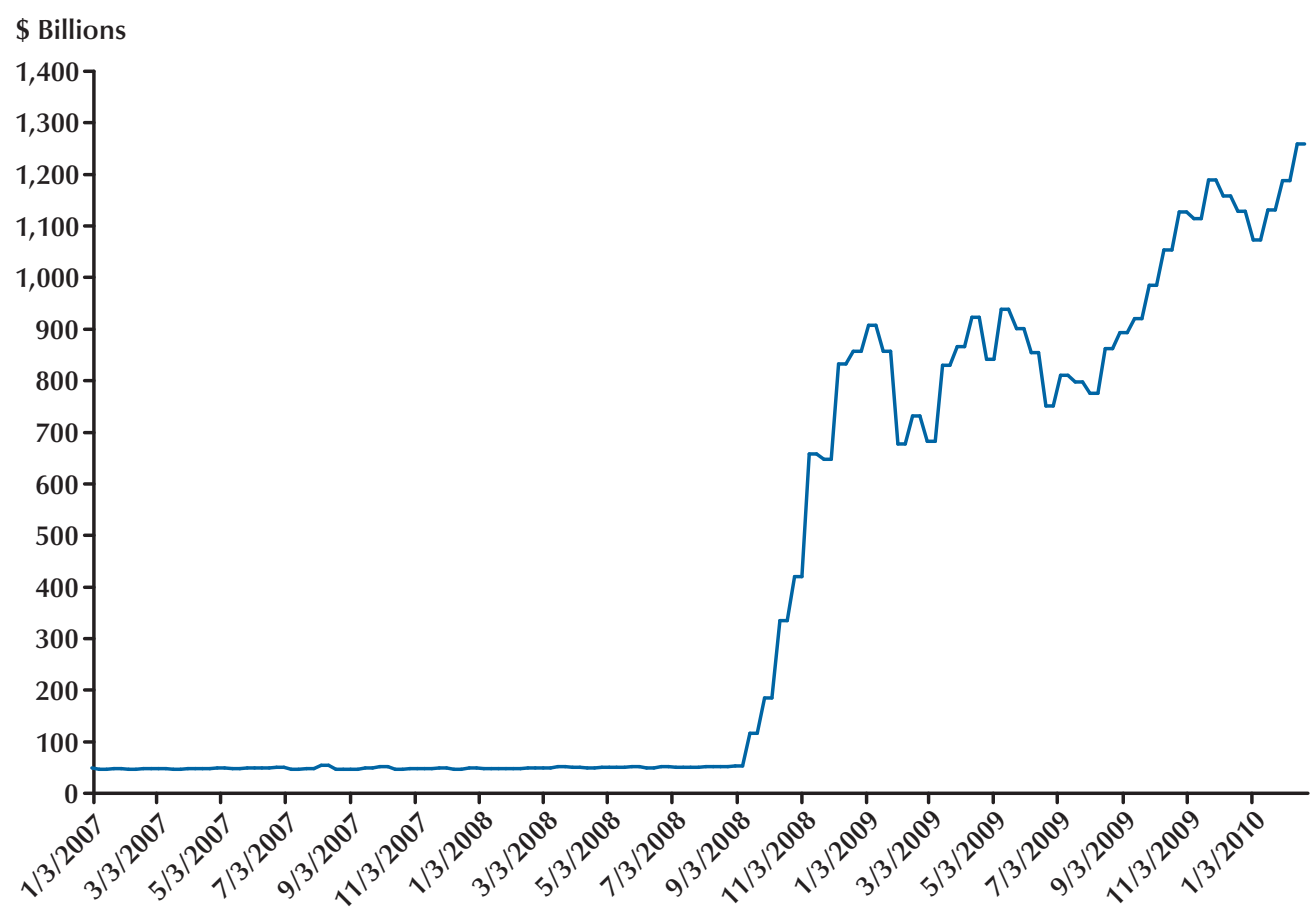

SOURCE: Federal Reserve.

stricken months of September through November 2008. ${ }^{17}$

This change in focus was both notable and smart. As mentioned earlier, riskless rates per se are almost irrelevant to economic activity. The traditional power of the funds rate derives from the fact that risk premiums between it and the (risky) rates that actually matter-rates on business and consumer loans, mortgages, corporate bonds, and so on-do not change much in normal times. Think of the interest rate on instrument $j$, say $R_{j}$, as being composed of the corresponding riskless rate, $r$, plus a risk premium specific to that instrument, say $\rho_{j}$. Thus $R_{j}=r+\rho_{j}$. If the $\rho_{j}$ changes little, then control of $r$ is a powerful tool for manipulating the interest rates that matterand hence aggregate demand. That is the normal

${ }^{17}$ As Michael Woodford pointed out to me, saving faltering institutions would also be expected to reduce risk spreads. case. But when the $\rho_{j}$ moves around a lot-in this case, rising — the funds rate becomes a weak policy instrument. During the most panicky periods, in fact, most of the $R_{j}$ s were rising even though $r$ was either constant or falling.

While I will say more about the Japanese experience later, one sharp contrast between quantitative easing in the United States and quantitative easing in Japan is worth pointing out right here. The BOJ concentrated its quantitative easing on reducing term premiums, mainly by buying long-term Japanese government bonds. By contrast, until it started purchasing long-term Treasuries in March 2009, the Fed's quantitative easing efforts concentrated on reducing risk premiums, which involved a potpourri of market-bymarket policies. It was far more complicated, to be sure, but in my view, also far more effective.

In fact, the one aspect of the Fed's quantitative easing campaign of which I have been critical 
is its purchases of Treasury bonds. The problem in many markets was that the sum $r+\rho_{j}$ was too high-but mainly because of sky-high risk premiums, not high risk-free rates. Thus the true target of opportunity was clearly $\rho_{j}$, not $r$, which was already very low. Furthermore, a steep yield curve provides profitable opportunities for banks to recapitalize themselves without taxpayer assistance. Why undermine that?

In any case, the Fed's quantitative easing attack on interest rate spreads appears to have been successful, at least in part. Figures 4 and 5 display two different interest rate spreads, one short term and the other long term. Figure 4 shows the spread between the interest rates on 3-month financial commercial paper and 3-month Treasury bills; Figure 5 shows the spread between Moody's Baa-rated corporate bonds and 10-year Treasury notes. The diagrams differ in details-for example, with short rates much more volatile than long rates. But both convey the same basic message: Once the Fed embarked on quantitative easing in a major way, spreads tumbled dramatically. Admittedly, other things were changing in markets at the same time; so this was far from a controlled experiment. Still, the "coincidence" in timing is suggestive.

\section{THE FED'S EXIT STRATEGY}

The Fed's exit is still in its infancy. Chairman Bernanke first outlined the major components of its strategy in his July 2009 Congressional testimony, followed by a speech in October 2009 and further testimonies in February and March 2010. ${ }^{18}$ So by now we have a pretty good picture of the Fed's planned exit strategy. Here are the key elements, listed in what may or may not prove to be the correct temporal order ${ }^{19}$ :

1. "In designing its [extraordinary liquidity] facilities, [the Fed] incorporated features... aimed at encouraging borrowers to reduce their use of the facilities as financial conditions returned to normal” (p. 4, note).

\footnotetext{
${ }^{18}$ Bernanke (2009a,b; 2010a,b).

${ }^{19}$ The quoted material is from Bernanke's February 2010 testimony.
}

2. "normalizing the terms of regular discount window loans" (p. 4).

3. "passively redeeming agency debt and MBS as they mature or are repaid" (p. 9).

4. "increasing the interest on reserves" (p. 7). ${ }^{20}$

5. "offer to depository institutions term deposits, which...could not be counted as reserves" (p. 8).

6. "reducing the quantity of reserves" via "reverse repurchase agreements" (p. 7).

7. "redeeming or selling securities" (p. 8) in conventional open-market operations.

Notice that this list deftly omits any mention of raising the federal funds rate. But the funds rate will presumably not wait until all the other steps have been completed. Indeed, Bernanke (2010a) noted that "the federal funds rate could for a time become a less reliable indicator than usual of conditions in short-term money markets," so that instead "it is possible that the Federal Reserve could for a time use the interest rate paid on reserves... as a guide to its policy stance” (p. 10). I will return to this not-so-subtle hint shortly.

The first and third items on this list are the parts of "quantitative tightening" that the Fed gets for free, analogous to letting assets run off naturally. As the Fed has noted repeatedly, its special liquidity facilities were designed to be unattractive in normal times, and Item 1 is by now almost complete. The Fed's two commercial paper facilities (one designed to save the money market mutual funds) outlived their usefulness, saw their usage drop to zero, and were officially closed on February 1, 2010. The same was true of the lending facility for primary dealers, the Term Securities Lending Facility, and the extraordinary swap arrangements with foreign central banks. The TAF and the MBS purchase program had been recently completed at that time, ${ }^{21}$ and the TALF was slated to follow suit at the end of June 2010.

\footnotetext{
${ }^{20}$ Congress authorized the payment of interest on bank reserves as part of its October 2008 emergency package.

21 This article is based on a lecture given on April 1, 2010; see the title page footnote.
} 
Figure 4

\section{Commercial Paper Versus T-Bill Risk Spread}

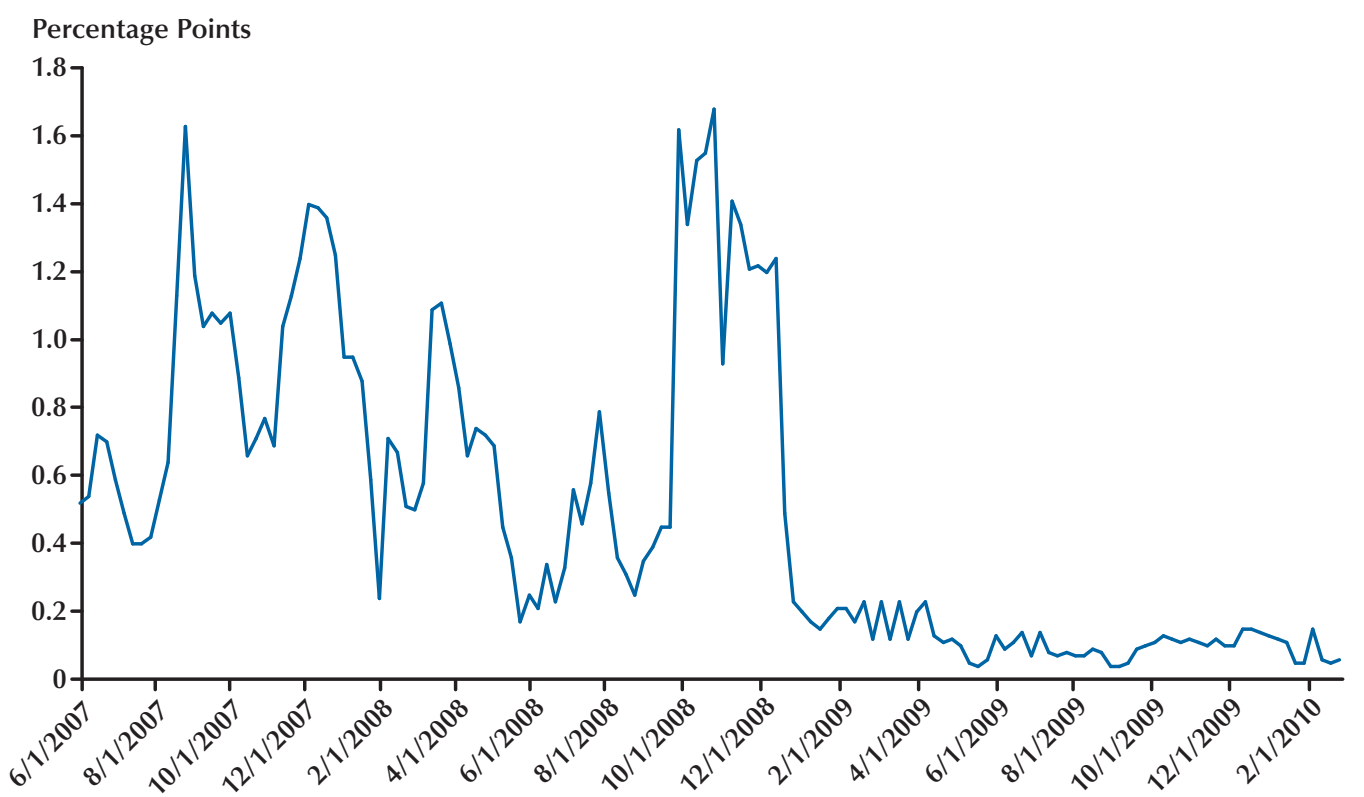

SOURCE: Federal Reserve.

Figure 5

\section{Corporate Bond Versus T-Note Risk Spread}

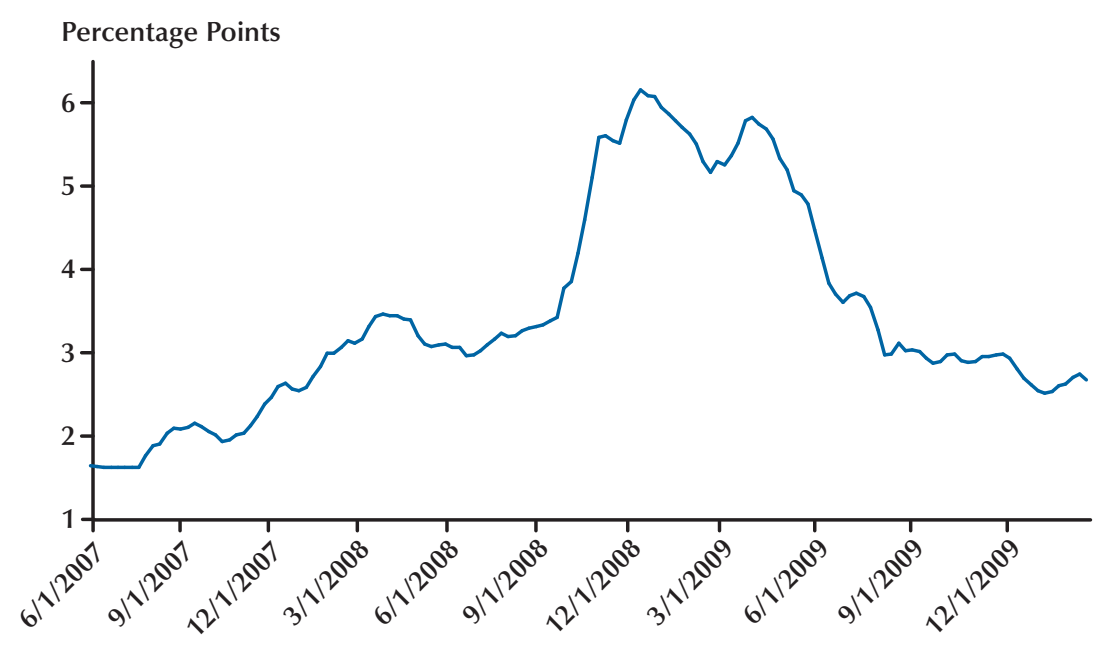

SOURCE: Federal Reserve. 
Item 2 on this list (raising the discount rate) is necessary to supplement Item 1 (making borrowing less attractive), and the Fed began doing so with a surprise intermeeting move on February 18, 2010. A higher discount rate is also needed if the Fed is to shift to the "corridor" system discussed later.

Note, however, that all these adjustments in liquidity facilities will still leave the Fed's balance sheet with the Bear Stearns and AIG assets and huge volumes of MBS and government-sponsored enterprise debt. Now that new purchases have stopped, the stocks of these two asset classes will gradually dwindle (Item 3 on the list). But unless there are aggressive open market sales, it will be a long time before the Fed's balance sheet resembles the status quo ante.

That brings me to Items 6 and 7 on Bernanke's list, which are two types of conventional contractionary open market operations, achieved either by reverse repurchases (repos) (and thus temporary) or by outright sales (and thus permanent). Transactions such as these have long been familiar to anyone who pays attention to monetary policy, as are their normal effects on interest rates.

However, there is a key distinction between Items 1 and 3 (lending facilities), on the one hand, and Items 6 and 7 (open market operations), on the other, when it comes to degree of difficulty. Quantitative easing under Item 1, in particular, wears off naturally on the markets' own rhythm: These special liquidity facilities fall into disuse as and when the markets no longer need them. From the point of view of the central bank, this is ideal because the exit is perfectly timed, almost by definition.

Items 6 and 7 are different. The FOMC will have to decide on the pace of its open market sales, just as it does in any tightening cycle. But this time, both the volume and the variety of assets to be sold will probably be huge. Of course, the FOMC will get the usual market and macro signals: movements in asset prices and interest rates, the changing macro outlook, inflation and inflationary expectations, and so on. But its decisionmaking will be more difficult, and more consequential, than usual because of the enormous scale of the tightening. If the Fed tightens too quickly, it may stunt or even abort the recovery. If it waits too long, inflation may gather steam. Once the Fed's policy rates are lifted off zero, short-term interest rates will presumably be the Fed's main guidepost once again-more or less as in the past.

This discussion leads naturally to Item 5 on Bernanke's list, the novel plan to offer banks new types of accounts "which are roughly analogous to certificates of deposit" (p. 8). That is, instead of just having a "checking account" at the Fed, as at present, banks will be offered the option of buying various certificates of deposit (CDs) as well. But here's the wrinkle: Unlike their checking account balances at the Fed, the CDs will not count as official reserves. Thus, when a bank transfers money from its checking account to its saving account, bank reserves will simply vanish.

The potential utility of this new instrument to a central bank wanting to drain reserves is evident, and the Fed has announced its intention to auction off fixed volumes of CDs of various maturities, probably ranging from one to six months. Such auctions would give it perfect control over the quantities but leave the corresponding interest rates to be determined by the market. Frankly, I wonder why banks would find these new fixedincome instruments attractive since they cannot be withdrawn before maturity, they do not constitute reserves, and they cannot serve as clearing balances. As a consequence, the new CDs may have to bear interest rates higher than those on Treasury bills. We'll see.

I come, finally, to the instrument that Bernanke and the Fed seem to view as most central to their exit strategy: the interest rate paid on bank reserves. Fed officials seem to view paying interest on reserves as something akin to the magic bullet. I hope they are right, but confess to being a bit worried. Everyone recognizes that the Fed's quantitative easing operations have created a veritable mountain of excess reserves (shown in Figure 3), which U.S. banks are currently holding voluntarily, despite the paltry rates paid by the Fed. The question is this: How urgent is it-or will it become-to whittle this mountain down to size?

One view sees all those excess reserves as potential financial kindling that will prove infla- 


\section{Figure 6}

\section{Interest Rate Floor System}

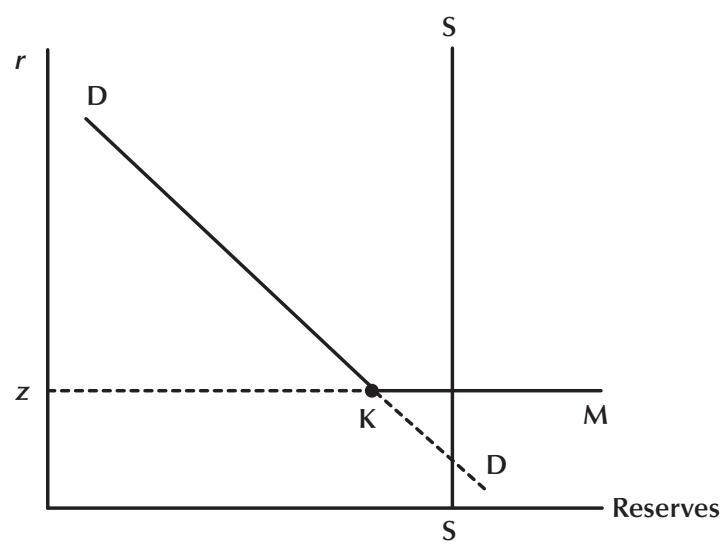

tionary unless withdrawn from the system as financial conditions normalize. ${ }^{22}$ We know that under normal circumstances-before interest was paid on reserves-banks' demand for excess reserves was virtually zero. But now that reserves earn interest, say at rate $z$, which the Fed sets, banks probably will not want to reduce their reserves all the way back to zero. Instead, excess reserves now compete with other very short-term safe assets, such as T-bills, in banks' asset portfolios. ${ }^{23}$ Indeed, one can argue that, for banks, reserves are now almost-perfect substitutes for T-bills. So excess reserve holdings will not need to fall all the way back to zero. Rather, the Fed's looming task will be to reduce the supply of excess reserves at the same pace that banks reduce their demands for them. The questions are how fast that pace will be and how far the process will go. Remember that as the Fed's liabilities shrink, so must its assets. So as the Fed reduces bank reserves, it must also reduce some of the loans and/or less-liquid assets now on its balance sheet.

There is, however, an alternative view that argues that the large apparent "overhang" of excess reserves is nothing to worry about. Specifically,

\footnotetext{
${ }^{22}$ See, for example, Meltzer (2010) and Taylor (2009).

${ }^{23}$ They will soon also compete with the new CDs just discussed.
}

\section{Figure 7}

\section{Interest Rate Corridor System}

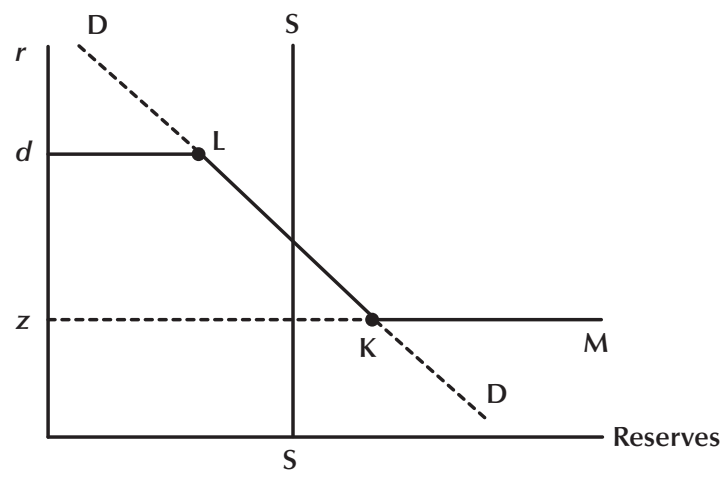

once the relevant market interest rate $(r)$ falls to the interest rate paid on reserves $(z)$, the demand for excess reserves becomes infinitely elastic (horizontal) at an opportunity cost of zero $(r-z=0)$, making the effective demand curve in Figure 6 DKM rather than DD. ${ }^{24}$ Another way to state the point is to note that banks will not supply federal funds to the marketplace at a rate below $z$ because they can always earn $z$ by depositing those funds with the Fed.

As Figure 6 shows, as long as the (vertical) supply curve of reserves, SS, which the Fed controls, cuts the demand curve in its horizontal segment, KM, the quantity of reserves should have no effect on the market interest rate, which is stuck at $z$. Therefore, the quantity of reserves should presumably have no effects on anything else either. Infinitely elastic demand presumably means that any volume of reserves can remain on banks' balance sheets indefinitely without kindling inflation. It also means that the Fed's exit decisions should concentrate on how quickly to shrink the assets side of its balance sheet. The liabilities side, in this view, is a passive partner that matters little per se.

\footnotetext{
24 See, for example, Keister, Martin, and McAndrews (2008) or Keister and McAndrews (2009).
} 
The idea of establishing either an interest rate floor, as depicted in Figure 6, or an interest rate corridor, as depicted in Figure 7, may become the Fed's new operating procedure. ${ }^{25}$ The corridor system starts with the floor (just explained) and adds a ceiling above which the funds rate cannot go. That ceiling is the Fed's discount rate, $d$, because no bank will pay more than $d$ to borrow federal funds in the marketplace if it can borrow at rate $d$ from the Fed. ${ }^{26}$ The Fed's policymakers can then set the upper and lower bounds of the corridor ( $d$ and $z$ ) and let the funds rate floatwhether freely or managed-between these two limits. Under such a system, the lower boundthe rate paid on reserves, $z$ - could easily become the Fed's active policy instrument, with the discount rate set mechanically, say, 100 basis points or so higher. ${ }^{27}$

If the federal funds rate were free to float within the corridor, rather than remaining stuck at the floor or ceiling, the Fed could use it as a valuable information variable. If the funds rate traded up too rapidly, that might indicate the Fed was withdrawing reserves too quickly, creating more scarcity than it wants. If funds traded down too far, that might indicate that reserves were too abundant-that is, the Fed was withdrawing them too slowly. Such information should help the Fed time its exit.

\section{QUANTITATIVE EASING AND TIGHTENING IN JAPAN}

Quantitative easing in Japan, the only relevant historical precursor, began in March 2001 and ended in March 2006 (Figure 8). The BOJ drove the overnight interest rate to zero and then pledged to keep it there until deflation ended, mainly by flooding the banking system with excess reserves.

\footnotetext{
${ }^{25}$ Bernanke (2010a, p. 9 note) elucidates the corridor idea.

${ }^{26}$ Obviously, this requires that discount window lending is neither rationed by, for example, window guidance nor limited by "stigma."

${ }^{27}$ There is an interesting sidelight here for Fed aficionados: At present, the authority to set the discount rate and the rate paid on reserves resides with the Board of Governors, not the FOMC, which sets the funds rate.
}

To create all those new reserves, the BOJ bought mostly Japanese government bonds, as mentioned earlier. The central idea behind quantitative easing in Japan was to stimulate the economy by proliferating reserves and flattening the (risk-free) yield curve, not by decreasing risk spreads. ${ }^{28}$

In fact, long bond rates did fall. But it is difficult to know how much of the decline was due to the BOJ's purchases and how much was due to its pledge to keep short rates near zero for a long while. Ugai's (2006) survey of empirical research on the effects of Japan's quantitative easing programs concluded that the evidence "confirms a clear effect" of the commitment policy on shortand medium-term interest rates but offers only "mixed" evidence that "expansion of the monetary base and altering the composition of the BOJ's balance sheet" had much effect. ${ }^{29}$

In any case, one of the more interesting and instructive aspects of quantitative easing in Japan may be how quickly it was withdrawn. Figure 8 shows that banks' excess reserves climbed gradually from about 5 trillion yen to about 33 trillion yen over the course of about two and a half years, but then fell back to only about 8 trillion yen over just a few months in 2006. Such an abrupt withdrawal of central bank money was, I suppose, driven by fears of incipient inflation-which was curious given Japan's recent deflationary history. In any case, inflation never showed up. While the suddenness of the BOJ's exit did not kill the economy, whether it hampered Japan's ability to stage a strong recovery is an open question.

In the case of the Fed, the massive increase in bank reserves after the Lehman bankruptcy came very quickly, as Figure 3 shows. The shrinkage, of course, has yet to begin. But my guess is that it will be gradual. If so, the Fed's pattern (up fast, down slow) will be just the opposite of the BOJ's (up slow, down fast). My second guess is that the Fed's more gradual withdrawal of quantitative easing will not unleash strong inflationary forces. And if that is correct, my third guess

\footnotetext{
${ }^{28}$ There were some purchases of private assets, but the BOJ concentrated on Japanese government bonds.

${ }^{29}$ The quoted material is from the paper's abstract.
} 


\section{Figure 8}

\section{Quantitative Easing in Japan}

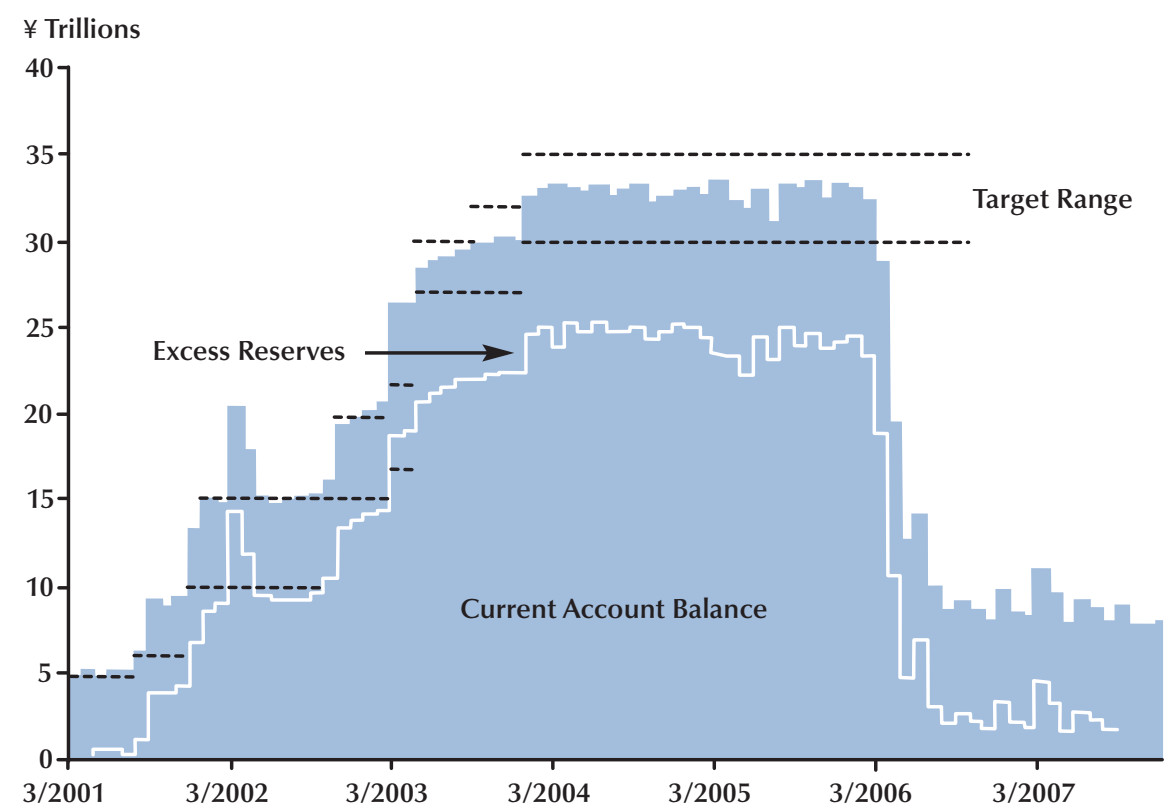

SOURCE: Bank of Japan.

follows: History will judge the Fed's course the wiser one. But all this is in the realm of conjecture right now. History will unfold at its own pace.

\section{IMPLICATIONS FOR CENTRAL BANK INDEPENDENCE}

Because many of the Fed's unorthodox quantitative easing policies put taxpayer money at risk, these policies constituted quasi-fiscal operations-equivalent to investing government funds in risky assets. ${ }^{30}$ But there was one big difference: Congress did not appropriate any money for this purpose. Some congressmen and senators are quietly happy that the Fed took these extraordinary actions on its own initiative. After all, doing so saved them from some politically horrific votes. ("Would you please vote $\$ 180$ billion for AIG, Senator?”) But others complain bitterly that

${ }^{30}$ At the margin, every dollar the Fed loses is the taxpayers' money. the Fed usurped authority that the Constitution reserves for Congress.

On that last point, it is worth quoting Section 13(3) of the Federal Reserve Act at some length, for it was invoked to justify these actions. It reads ${ }^{31}$ :

In unusual and exigent circumstances, the Board of Governors of the Federal Reserve System, by the affirmative vote of not less than five members, may authorize any Federal reserve bank, during such periods as the said board may determine...to discount for any individual, partnership, or corporation, notes, drafts, and bills of exchange when such notes, drafts, and bills of exchange are indorsed or otherwise secured to the satisfaction of the Federal Reserve bank (emphasis added).

The three bold-faced phrases emphasize the three salient features of this section. First, the

\footnotetext{
31 Section 13(3) was added to the Federal Reserve Act in 1932 and last amended in 1991
} 
circumstances must be extraordinary ("unusual and exigent"). Second, the law allows the Fed to lend to pretty much anyone, without restriction, as long as it takes good collateral. Third, the Fed itself gets to judge whether the collateral is good. In a system of government founded on checks and balances, that provision constitutes an extraordinary grant of power. But reading the law does at least answer one narrow question: The Fed did not overstep its legal authority; that authority was and is extremely broad.

The real question is whether Section 13(3) grants the central bank too much unbridled power. My tentative answer is yes, especially since Section 13(3) interventions tend to put taxpayer funds at risk and to be institution specifictwo characteristics that make them inherently political. Still, getting timely congressional votes to address "unusual and exigent" circumstances can be very difficult. Remember, the Troubled Asset Relief Program (TARP) failed on the first vote. Balancing those two considerations leads me to recommend something similar to the provisions in the House and Senate bills: In order to invoke Section 13(3) powers, the Fed should need approval from some other authority, such as the Secretary of the Treasury, acting on behalf of the president. ${ }^{32}$ Then, as soon as is practicable, the Fed should report to the two banking committees of Congress on exactly what it did, why it made those decisions, and whether it expects to incur any losses on the transactions. ${ }^{33}$ Those two steps would go a long way toward filling the democracy deficit. ${ }^{34}$

But the broader question is this: How far beyond conventional monetary policy should the doctrine of central bank independence be extended? Remember, the Federal Reserve has never had nearly as much independence in the sphere of bank supervision and regulation, where

\footnotetext{
${ }^{32}$ Both bills require the approval of the proposed Financial Stability Oversight Council, which is to be chaired by the Secretary of the Treasury. The House bill also requires explicit approval from the Treasury secretary.

${ }^{33}$ This report should probably be kept confidential for a while, as both bills recognize.

${ }^{34}$ The Dodd-Frank Act was passed several months (July 21, 2010) after this lecture was given.
}

it shares power with three other federal banking agencies, as it has in monetary policy. So, for example, if the Fed were to be made the systemic risk regulator, should it be as independent in that role as it is in monetary policy? Or should it be given something more like primus inter pares status? It's a fair question, without a clear answer.

Another variant of the same question arises when some of the quasi-fiscal operations justified by Section 13(3) come to constitute all or most of the Fed's monetary policy. Such a situation is, of course, not hypothetical. Since December 2008, the FOMC's undisputed control of the federal funds rate has given it no leverage over the economy whatsoever because the funds rate is constrained to essentially zero, and hence immobilized. Indeed, one might argue that, until just recently, the Fed's most important monetary policy instruments were its asset purchases. ${ }^{35}$

\section{WRAPPING UP}

When the FOMC met on August 7, 2007, and declared that inflation was still a bigger threat than unemployment, no one could have guessed what the coming years would bring. When the FOMC met on September 16, 2008, the day after the Lehman bankruptcy, probably no one imagined what the Fed would wind up doing over the next six months. The quantitative easing policies that began as a trickle in 2007, but became a flood after the Lehman failure, may have changed the Fed forever. They have certainly raised numerous questions about its policy options, its operating procedures, and its position within the U.S. government.

The Fed's entrance strategy into quantitative easing was ad hoc and crisis driven at first, but it became more orderly and thoughtful as time went by. It was a wonderful example of learning by doing. But the Fed now finds itself on an alien planet, with a near-zero funds rate, a two-trillion-

\footnotetext{
${ }^{35}$ Both the House and Senate bills draw sharp distinctions between Section 13(3) lending to specific institutions, which would be prohibited, and more generic Section 13(3) lending aimed at markets, which would be allowed. The latter is, arguably (unconventional) monetary policy.
} 
dollar balance sheet, a variety of dodgy assets, holes in the wall separating the Fed from the Treasury, Congress up in arms, and its regulatory role up in the air.

Your mission, Mr. Bernanke, since you've chosen to accept it, is to steer the Federal Reserve back to planet Earth, using as principal aspects of your exit strategy some new instruments you have never tried before. As always, should you or any member of the Fed fail, the Secretary and Congress will disavow any knowledge of your actions. This lecture will self-destruct in five seconds. Good luck, Ben.

\section{REFERENCES}

Bernanke, Ben S. "Semiannual Monetary Policy Report to the Congress." Testimony before the Committee on Financial Services, U.S. House of Representatives, Washington, DC, July 21, 2009a; www.federalreserve.gov/newsevents/testimony/bernanke20090721a.htm.

Bernanke, Ben S. “The Federal Reserve’s Balance Sheet: An Update.” Speech at the Federal Reserve Board Conference on Key Developments in Monetary Policy, Washington, DC, October 8, 2009b; www.federalreserve.gov/newsevents/speech/bernanke20091008a.htm.

Bernanke, Ben S. "Federal Reserve's Exit Strategy.” Testimony before the Committee on Financial Services, U.S. House of Representatives, Washington, DC, February 10, 2010a; www.federalreserve.gov/newsevents/testimony/bernanke20100210a.htm.

Bernanke, Ben S. "Federal Reserve's Exit Strategy.” Testimony before the Committee on Financial Services, U.S. House of Representatives, Washington, DC, March 25, 2010b; www.federalreserve.gov/newsevents/testimony/bernanke20100325a.htm.

Blinder, Alan S. The Quiet Revolution: Central Banking Goes Modern. New Haven, CT: Yale University Press, 2004.

Curdía, Vasco and Michael Woodford. "The Central-Bank Balance Sheet as an Instrument of Monetary Policy." Presented at the 75th Carnegie-Rochester Conference on Public Policy, "The Future of Central Banking," April 16-17, 2010; www.carnegie-rochester.rochester.edu/april10-pdfs/Curdia\%20Woodford.pdf.

Friedman, Milton. "The Role of Monetary Policy.” American Economic Review, March 1968, 58(1), pp. 1-17.

Keister, Todd; Martin, Antoine and McAndrews, James. "Divorcing Money from Monetary Policy.” Federal Reserve Bank of New York Economic Policy Review, September 2008, pp. 41-56; www.newyorkfed.org/research/EPR/08v14n2/0809keis.pdf.

Keister, Todd and McAndrews, James. "Why Are Banks Holding So Many Excess Reserves?” Federal Reserve Bank of New York Current Issues in Economics and Finance, December 2009, 15(8), pp. 1-10; www.newyorkfed.org/research/current issues/ci15-8.pdf.

Krugman, Paul R. "It’s Baaack: Japan's Slump and the Return of the Liquidity Trap.” Brookings Papers on Economic Activity, 1998, 29(2), pp. 137-205.

Meltzer, Allan. “The Fed's Anti-Inflation Exit Strategy Will Fail.” Wall Street Journal, January 27, 2010.

Modigliani, Franco and Sutch, Richard. "Innovations in Interest Rate Policy." American Economic Review, March 1966, 56(1/2), pp. 178-97.

Reifschneider, David and Williams, John C. "Board Staff Presentation to the FOMC on the Implications of the Zero Bound on Nominal Interest Rates." Federal Reserve Board of Governors, January 29, 2002; www.federalreserve.gov/monetarypolicy/files/FOMC20020130material.pdf (see Appendix 3, pp. 157-64). 
Svensson, Lars E.O. "Escaping from a Liquidity Trap and Deflation: The Foolproof Way and Others." Journal of Economic Perspectives, Fall 2003, 17(4), pp. 145-66.

Taylor, John B. “An Exit Rule for Monetary Policy.” Unpublished manuscript, Stanford University, February 10, 2010; www.stanford.edu/ johntayl/House \% 20FSC \%20Feb\%2010\% 202010.pdf.

Taylor, John B. “The Need for a Clear and Credible Exit Strategy,” in John Ciorciari and John Taylor, eds., The Road Ahead for the Fed. Chap. 6. Stanford, CA: Hoover Institution Press, 2009, pp. 85-100.

Taylor, John B. and Williams, John C. “A Black Swan in the Money Market.” American Economic Journal: Macroeconomics, January 2009, 1(1), pp. 58-83.

Ugai, Hiroshi. "Effects of the Quantitative Easing Policy: A Survey of the Empirical Evidence.” Bank of Japan Working Paper No. 06-E-10, July 2006; www.boj.or.jp/en/type/ronbun/ron/wps/data/wp06e10.pdf. 
